\title{
A comparison of the morbidity and mortality of tandir burns and non-tandir burns: experience in two centers
}

\author{
Tandır ve tandır dışı yanıkların morbidite ve mortalitelerinin karşılaştırılması: \\ İki merkez deneyimi
}

\author{
Yavuz ALBAYRAK, ${ }^{1}$ Cumhur ÇAKIR,${ }^{2}$ Ayşe ALBAYRAK, ${ }^{3}$ Belkiz AYLU ${ }^{1}$
}

\section{BACKGROUND}

We examine herein the demographic characteristics, implemented treatment methods, infection rates, and morbidities of patients with tandir burns from two burn centers.

\section{METHODS}

In this study, gender, age, socioeconomic status, total body burn ratio, burn area, burn level, microorganisms isolated in burn wounds, implemented treatments, length of hospital stay, debridement and grafting operations, extremity amputations, and mortality among burn patients were investigated.

\section{RESULTS}

Tandir burn patients were treated in the hospital for an average of $27.6 \pm 9.5$ days, while non-tandir burn patients were treated for a period of $16.5 \pm 12.5$ days. A significant difference was found between the hospitalization periods of the two groups $(p<0.001)$. Similarly, while the total burn surface area average of the tandir burn patients was $17.4 \%$ $\pm 12.3 \%$, the total burn surface area average of the nontandir burn patients was $10.6 \% \pm 9.9 \%$, and a significant difference was found between the two $(p<0.001)$.

\section{CONCLUSION}

In our study, it was determined that tandir burns were deeper than other burns, and that hospitalization durations were longer than for other burn causes. Surgical intervention was also more prevalent among patients with tandir burn than among those with other burn causes.

Key Words: Burn; debridement; extremity amputation; grafting; Pseudomonas aeruginosa; tandir burn.

\section{$\boldsymbol{A M A C}$}

İki ayrı yanık tedavi merkezinde tandıra düşme sonucu yanık oluşan hastaların demografik özellikleri, enfeksiyon oranları ve mobidite oranları tedavi yöntemleri ile birlikte incelendi.

\section{GEREÇ VE YÖNTEM}

Bu çalışmada yanıklı hastaların yaş, cinsiyet, sosyoekonomik durum, toplam vücut yüzey yanık oranları, yanık bölgeleri, yanık yaralarından izole edilen mikroorganizmalar, tedavi yöntemleri, hastanede kalma süreleri, hastalara uygulanan debridman ve greft operasyonları, ekstremite amputasyonları ile yanık hastalarının mortaliteleri araştırıldı.

\section{BULGULAR}

$\mathrm{Bu}$ iki merkezde tedavi edilen tandır yanıklı hastaların ortalama hastanede kalma süresi 27,6 $\pm 9,5$ gün idi. Buna karşın tandır dışı yanıklı hastaların ortalama hastanede kalma süresi ise $16,5 \pm 12,5$ gün idi. Bu iki grup arasında hastanede kalma süreleri arasında anlamlı derecede farklılık saptand $1(\mathrm{p}<0,001)$. Benzer şekilde tandır yanıklı hastaların toplam yanık yüzey alan ortalaması $\% 17,4 \pm 12,3$ iken tandır dışı yanıklı hastaların toplam yanık yüzey alan ortalaması $\% 10,6 \pm 9,9$ idi ve gruplar arasındaki fark anlamlı idi $(\mathrm{p}<0,001)$.

\section{SONUÇ}

$\mathrm{Bu}$ çalışma sırasında tandır yanıklarının diğer yanıklardan daha derin yanık oluşturduğunu ve hastanede kalma süresinin de diğer yanık türlerinden daha uzun olduğu sonucuna ulaştık. Yine cerrahi girişimlerin tandır yanıklı hastalarda diğer yanıklı hastalara göre daha fazla yapıldığını tespit ettik.

Anahtar Sözcükler: Yanık; debridman; ekstremite amputasyonu; greftleme; Pseudomonas aeruginosa; tandır yanığı.
Departments of ${ }^{1}$ General Surgery, ${ }^{3}$ Infectious Diseases and Clinical Microbiology, Erzurum Region Training and Research Hospital, Erzurum; ${ }^{2}$ Department of General Surgery, Van State Hospital, Van, Turkey.
Erzurum Bölge Eğitim ve Araștırma Hastanesi, ${ }^{1}$ Genel Cerrahi Kliniği, ${ }^{3}$ Enfeksiyon Hastalıkları ve Klinik Mikrobiyoloji Kliniği, Erzurum; ${ }^{2}$ Van Devlet Hastanesi, Genel Cerrahi Kliniği, Van. 
A burn is a complex trauma of varying severity ranging from a minor degree burn to a full body burn, and severe burns may be fatal. Burn injuries continue to be a common health problem throughout the world and a cause of concern in most societies because of their morbidity. ${ }^{[1,2]}$ Burns may be caused by a variety of fires, scalding agents, chemicals, electricity, and radiation. In developed countries, all these agents cause burns with variable severity, but their late results include late-stage deformities and can, in general, be predicted. ${ }^{[3]}$ The etiological factors of burn injuries vary in different countries. The "tandir", an in-ground oven used especially in eastern Turkey for baking bread, is another important cause of burns. Tandir burns, due to the characteristics of the tandir, are burns with large surface areas. ${ }^{[3,4]}$ Therefore, it may be reasoned that their morbidity is high, but there are no studies in the literature on this point.

In this article, we present the demographic characteristics, implemented treatment methods, infection rates, and morbidities of patients with tandir burns. We also examine burns resulting from other factors among patients from two burn centers in the provinces of Erzurum and Van, located in eastern Turkey.

\section{MATERIALS AND METHODS}

Seven hundred and eighty-five in-patients were treated at Erzurum Region Training and Research Hospital Burn Treatment Center and Van State Hospital Burn Treatment Center between November 2008 and August 2010. These two burn treatment centers serve patients from other neighboring provinces in addition to the provinces of Erzurum and Van (Fig. $1)$. The population of the region served by the centers is 5,572,854, with 2,845,920 males and 2,726,934 females (the population of Turkey is 72,561,312; $36,462,470$ males and 36,098,842 females). ${ }^{[5]}$

In this study, gender, age, socioeconomic status, total body burn ratio, burn area, burn level, microorganisms isolated in burn wounds, implemented treatments, length of hospital stay, debridement and grafting operations, extremity amputations, and mortality

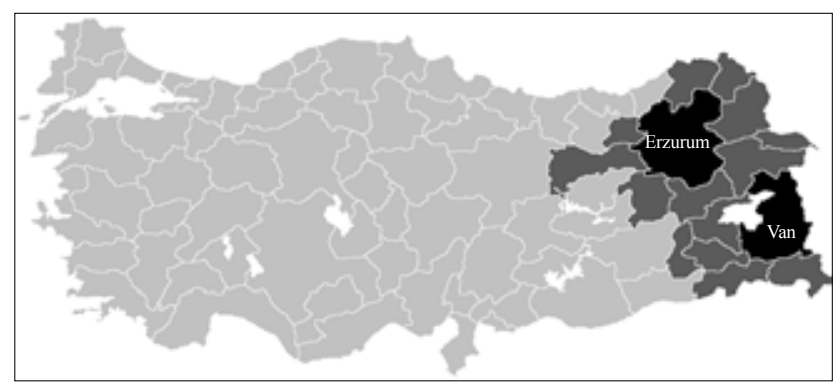

Fig. 1. The provinces in eastern Turkey, where the study was carried out (shaded dark), and neighboring cities referring burn patients to these centers (shaded light). of burn patients were investigated. The infection control specialist performed retrospective surveillance for nosocomial infection on all hospital wards. This was accomplished through regular interactions with burn staff nurses and daily review of microbiology laboratory reports, by gathering additional information about each patient with nosocomial infection, including the date and site of infection and culture results. All of the patients were given proton pump inhibitors for stress ulcer prophylaxis. A few of the patients required total parenteral nutrition, fresh frozen plasma, albumin, and blood transfusion.

Data are expressed as mean \pm SD. Differences between the two groups (tandir burns and non-tandir burns) were analyzed using the independent Student's t-test. Chi-square tests were used for the categorical variables where appropriate. Homogeneity of variances was calculated by Levene's test. All statistical calculations were done using the program SPSS for Windows (version 11.00; SPSS, Inc., Chicago, IL). Differences were considered statistically significant at levels of probability of $\mathrm{p}<0.05$.

\section{RESULTS}

Sixty-nine $(8.8 \%)$ of the in-patients were patients with tandir burns. The most frequent cause of burn was scalding from hot water (513 cases, $65.4 \%)$. The other causes, in order of descending frequency, were flame ( 71 cases, $9.1 \%$ ), tandir (69 cases, $8.8 \%$ ), electrical (47 cases, $6.0 \%$ ), other liquid materials (37 cases, $4.7 \%)$, contact with hot surfaces/materials such as a stove or iron (23 cases, $2.9 \%$ ), vapor ( 8 cases, $1.0 \%$ ), and other burns (17 cases, $2.1 \%$ ).

Of the tandir burn patients, 47 (68.1\%) were female and $22(31.9 \%)$ were male. Three hundred and forty $(47.5 \%)$ of the non-tandir burn victims were female, and $376(52.5 \%)$ were male. The age, place of residence, education, and socioeconomic status of the burn patients are shown in Table 1. There were no differences in the average ages of the tandir burn patients and non-tandir burn patients ( $p>0.05)$. However, when the patients were grouped according to their gender or age into 4 groups as $0-6,7-16,17-45$ and $>46$ years, significant differences were determined between tandir burns and non-tandir burns $(p<0.001)$. The socioeconomic status of the patients was categorized into three groups as: monthly income $<$ USD 400 , monthly income USD 400 - USD 800, and monthly income $>$ USD 800 . Of the tandir burn patients, 38 (55.1\%) were in the first group, $28(40.6 \%)$ in the second group and $3(4.3 \%)$ in the third group. Of the non-tandir burn patients, $178(24.9 \%)$ were in the first group, 467 $(65.2 \%)$ in the second group and $71(9.9 \%)$ in the third group. There was also a significant difference between tandir and non-tandir burn patients in the socioeconomic status domain $(\mathrm{p}<0.001)$. 
Table 1. Age groups of tandir and non-tandir burn patients, level of education (of the patient or their parents), and their socioeconomic status

\begin{tabular}{|c|c|c|c|c|c|c|c|c|c|c|c|c|}
\hline & \multirow[b]{2}{*}{$\begin{array}{l}\text { Place of } \\
\text { residence } \\
(\mathrm{C} / \mathrm{R})\end{array}$} & \multicolumn{4}{|c|}{ Age groups (n / \%) } & \multicolumn{4}{|c|}{ Level of education $(\mathrm{n} / \%)$} & \multicolumn{3}{|c|}{ Socioeconomic status (n / \%) } \\
\hline & & $0-6(y)$ & $7-16(y)$ & $17-45(y)$ & $46-90(y)$ & E1 & E2 & E3 & E4 & Poor & Med. & Good \\
\hline Tandir burns & $1 / 68$ & $52 / 75.4 \%$ & $2 / 2.9 \%$ & $9 / 13.0 \%$ & $6 / 8.7 \%$ & $10 / 14.5 \%$ & $28 / 40.6 \%$ & $26 / 37.7 \%$ & $5 / 7.2 \%$ & $3 / 4.3 \%$ & $28 / 40.6 \%$ & $38 / 55.1 \%$ \\
\hline Non-tandir burns & $183 / 533$ & $389 / 54.3 \%$ & $108 / 15.1 \%$ & $168 / 23.5 \%$ & $51 / 7.1 \%$ & $113 / 15.8 \%$ & $302 / 42.2 \%$ & $269 / 37.6 \%$ & $32 / 4.5 \%$ & $68 / 9.5 \%$ & $469 / 65.5 \%$ & $179 / 25.0 \%$ \\
\hline $\mathrm{p}^{*}$ & $\mathrm{p}<0.001$ & \multicolumn{4}{|c|}{$\mathrm{p}<0.001$} & \multicolumn{4}{|c|}{$\mathrm{p}<0.001$} & \multicolumn{3}{|c|}{$\mathrm{p}>0.05$} \\
\hline
\end{tabular}

C: Those living in the city or town center; R: Those living away from the center or in rural areas; E1: Illiterate; E2: Primary school graduate or literate; E3: Secondary schooling; E4: University or postgraduate; Poor: Income less than minimum wage; Med.: Medium, income between minimum wage and 3 times minimum wage; Good: Income more than 3 times the minimum wage.

The treatment protocol of both centers consists of fluid replacement, wound treatment and surgical procedures. Fluid resuscitation was performed according to the Parkland formula in all patients. ${ }^{[6]}$ Nutritional support was given based on the caloric and protein needs of the patients, parenterally and orally (preferred) if possible. Parenteral nutrition was used for 3 of the patients. Given that tandir burns are usually deep, seconddegree and third-degree burns and eschars are formed in most of these patients. As mafenide acetate is not available in our country, tub hydrotherapy was applied and the burns were dressed with silver sulfadiazine.

Escharotomy, debridement, grafting and amputation procedures were applied where relevant. Table 2 shows the age, gender, burn percentage, burn area, and the implemented surgical procedures of the burn patients. Tandir burn patients were treated in the hospital for an average of $27.6 \pm 9.5$ days, while non-tandir burn patients were treated for a period of $16.5 \pm 12.5$ days. A significant difference was found between the hospitalization periods of the two groups $(p<0.001)$. Similarly, while the total burn surface area average of the tandir burn patients was $17.4 \% \pm 12.3 \%$, the total burn surface area average of the non-tandir burn patients was $10.6 \pm 9.9 \%$, and a significant difference was found between the two $(\mathrm{p}<0.001)$.

In general, in the absence of a high burn percentage, patients are not started on prophylactic antibiotics treatment. Suitable antibiotherapies are implemented according to the results of cultures taken during the hospitalization of the patient, and with the opinion of the Infectious Diseases Specialist. The microorganism most frequently isolated in the burn lesion cultures of the patients included in our study was Pseudomonas aeruginosa $(19.9 \%)$. The other microorganisms identified from cultures were methicillin-resistant Staphylococcus aureus (MRSA) (10.2\%), methicillin-resistant coagulase-negative Staphylococci (MRCNS) (3.1\%), Escherichia coli (2.7\%), Enterobacter spp. (2.5\%), methicillin-sensitive coagulase-negative Staphylococci (MSCNS) (4.2\%), Enterococcus spp. (2.2\%), and others $(3.2 \%)$ (Table 3$)$. A significant difference was determined between the proliferation of microorganisms in cultures of tandir burns and non-tandir burns $(p<0.001)$. Mortality in tandir burn patients was $4.4 \%$, and in non-tandir burn patients was $1.3 \%$.

Table 2. Comparison of group data for age, gender, burn characteristics, treatment, and hospitalization time

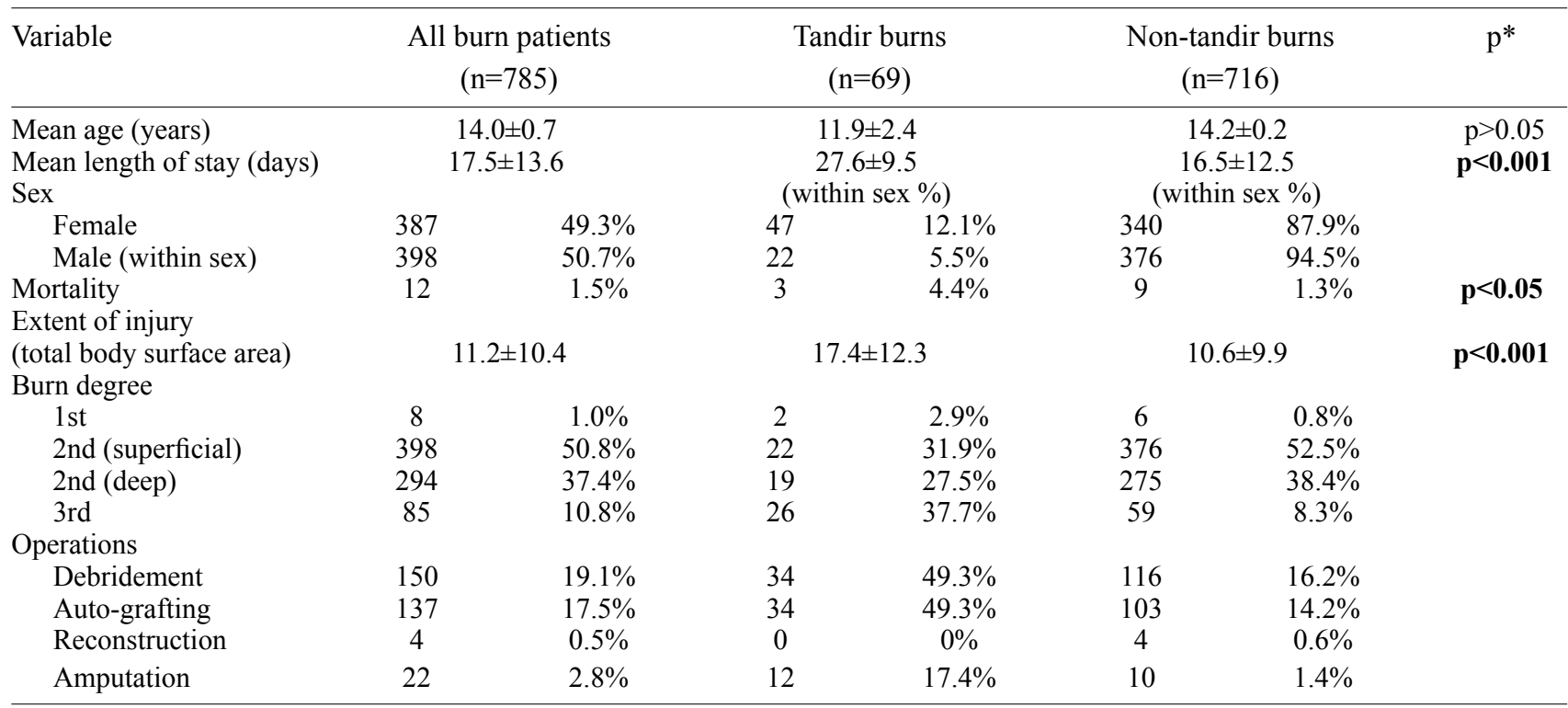

* $p$ value estimated by chi-square tests for categorical variables and Student's t-test for continuous variables between tandir burns and non-tandir burns. 
Table 3. The distribution of organisms isolated from burn patients

\begin{tabular}{|c|c|c|c|c|c|c|c|}
\hline \multirow{2}{*}{$\begin{array}{l}\text { Microorganisms } \\
\text { P. aeruginosa }\end{array}$} & \multicolumn{2}{|c|}{$\begin{array}{l}\text { All burn patients } \\
\qquad(\mathrm{n}=785)\end{array}$} & \multicolumn{2}{|c|}{$\begin{array}{l}\text { Tandir burns } \\
(n=69)\end{array}$} & \multicolumn{2}{|c|}{$\begin{array}{l}\text { Non-tandir burns } \\
\qquad(\mathrm{n}=716)\end{array}$} & \multirow[t]{2}{*}{$\mathrm{p}^{*}$} \\
\hline & 156 & $19.9 \%$ & 18 & $29.0 \%$ & 138 & $26.1 \%$ & \\
\hline MRSAa & 80 & $10.2 \%$ & 11 & $17.7 \%$ & 69 & $15.9 \%$ & \\
\hline MRCNSb & 24 & $3.1 \%$ & 3 & $4.8 \%$ & 21 & $4.3 \%$ & \\
\hline E. coli & 21 & $2.7 \%$ & 7 & $11.4 \%$ & 14 & $2.2 \%$ & \\
\hline Enterobacter & 20 & $2.5 \%$ & 6 & $9.7 \%$ & 14 & $10.1 \%$ & \\
\hline MSCNSc & 17 & $2.2 \%$ & 0 & $0.0 \%$ & 17 & $0 \%$ & \\
\hline Enterococcus & 17 & $2.2 \%$ & 7 & $11.3 \%$ & 10 & $2.2 \%$ & \\
\hline Others & 25 & $3.2 \%$ & 10 & $16.1 \%$ & 15 & $14.5 \%$ & \\
\hline Total & 374 & & 62 & & 312 & & $\mathrm{p}<0.001$ \\
\hline
\end{tabular}

a: Methicillin-resistant Staphylococcus aureus; b: Methicillin-resistant coagulase-negative Staphylococci; c: Methicillin-sensitive coagulase-negative Staphylococci.

\section{DISCUSSION}

A burn is one of the most severe injuries. The burn causes and demographic features associated with burn injury differ in each country. The most common agents are scalding liquids (65\%) followed by flames (15$23 \%) \cdot{ }^{[4,7-9]}$ In our study, the most frequent burn cause was found to be scalding, followed by flame burns, tandir burns and electricity burns.

In some rural areas of Turkey, people prefer to bake bread themselves. To this end, different methods are used in different areas. Two types of ovens are used most frequently. One is a simple oven, similar in appearance to modern bread-baking ovens and used extensively in most regions of Turkey (Fig. 2). As discussed above, the second is the oven named tandir, and it is used specifically in the eastern and southeastern regions of Turkey (Fig. 2). The tandir is a deep, pit-like structure. The bread dough is attached to the side walls of the pit, which accumulate heat from the wood burned in the bottom, thereby baking the bread. Tandir burns are usually the result of a fall into the pit-like tandir. Therefore, especially the extremities, and sometimes the head and torso, are subjected to a temperature of approximately $450^{\circ} \mathrm{C}$ for a lengthy period.

In this study, we have presented the tandir burn and non-tandir burn case experiences in two separate burn centers in the region where tandir burns are encountered most frequently. Our patients were generally from the eastern region of Turkey (Fig. 1). The total population of this area is 5,572,854. ${ }^{[5]}$ Sex and age are linked with developmental and behavioral patterns, and are important determinants of risk for serious burn injury. ${ }^{[10,11]}$ van Rijn et al. ${ }^{[12]}$ reviewed the literature on the causes of burns in developed countries, and they found that the incidence of burn injury was much higher in children under four years of age. During our research, we also determined that tandir burns are most frequent among women and young children. We found that children under six years of age were at high risk for severe tandir-related burn injury. Another single center study in our region also reported that children under the age of six are the group most affected by tandir burns. ${ }^{[4]}$ Similarly, another study

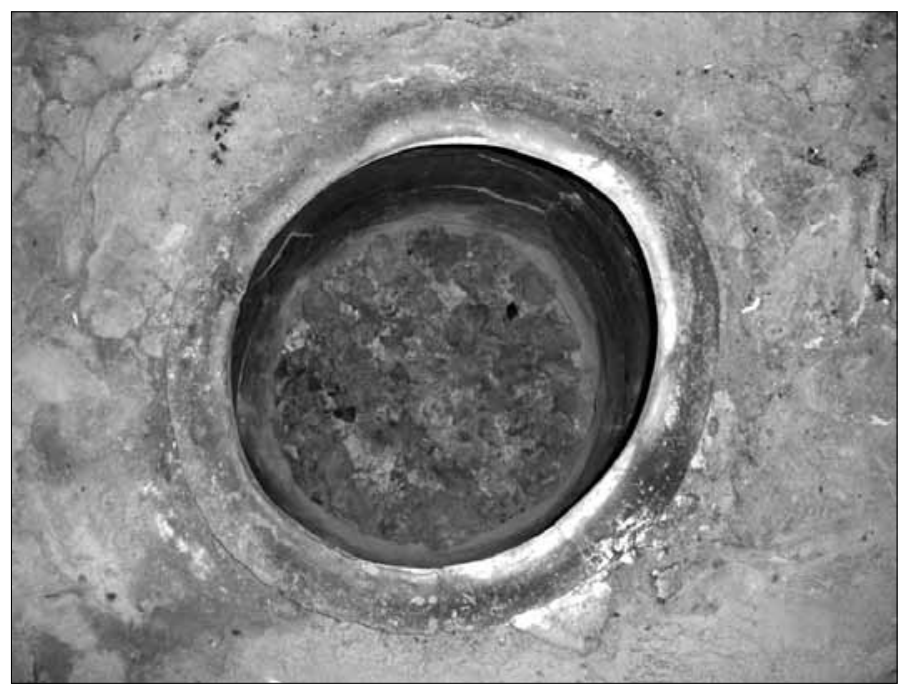

Fig. 2. Image of a tandir oven used for baking bread. 
carried out in our region reported that, of the 15 tandir burn cases, seven affected children under the age of eight. ${ }^{[13]}$ A study carried out by Bekerecioğlu et al., ${ }^{[3]}$ in the region where the second center of our study is located, also indicated that most of the tandir burns occurred among children. Tandir burns are more frequently encountered in women and children, because bread baking is a job typically carried out by women, and small children are usually with the women (generally their mothers). This danger needs to be emphasized in Turkish public education projects related to preventive medicine.

The majority of our non-tandir burn patients were from rural areas. All of the tandir burn cases except one lived in rural areas. The one exception, although a resident in the city center, was burned during a visit to relatives living in a village. This result is expected in rural areas where the use of tandir is extensive. However, tandir burn cases are being reported only in the eastern and southeastern regions of Turkey. As a result, the use in this region of the safer oven utilized in other parts of the country is essential and must be encouraged, and national educational programs on the subject should be started.

The commonest microorganisms seen in the cultures were $P$. aeruginosa and $S$. aureus (MRSA). Akcay et al..$^{[4]}$ and $\mathrm{Al}$ et al. ${ }^{[14]}$ reported that antibiotics were started in every tandir burn patient. We have a more cooperative infectious disease specialist and microbiologist, enabling us to introduce anti-infective microbiological and antibiotic policies into the unit. Infectious disease specialists visit our burn centers daily, and necessary antimicrobial treatments are started based upon their suggestion. We were able to detect organisms causing sepsis early, enabling us to institute appropriate antibiotics expeditiously. ${ }^{[2,15]}$ This helped in controlling the sepsis and preventing multiorgan failure. Although there was a significant difference between tandir burn patients and non-tandir burn patients in the proliferation of nosocomial infection agents in the lesion cultures, there was no difference in the occurrence of nosocomial sepsis. We are also of the opinion that risk of growth of resistant microorganisms in our centers is minimized since prophylactic antibiotics treatment is not used.

In our study, it was determined that tandir burns were deeper than other burns, and that hospitalization durations were longer than for other burn causes. Other research regarding tandir burns has also reported similar hospitalization periods. ${ }^{[4,14]}$ Surgical intervention (amputations, escharotomy, fasciotomy, etc.) was also more prevalent among tandir burn patients than among those with other burn cause. This is due to the fact that tandir burns are caused by patients falling into the tandir pits and remaining in direct contact with ap- proximately $450^{\circ} \mathrm{C}$ heat, especially the extremities, for long periods, resulting in deeper and more extensive burns. For this reason, the treatment of tandir burn patients before their arrival at the hospital must be correctly and rapidly carried out. Akcay et al. ${ }^{[4]}$ also reported that surgical procedures were carried out more often for tandir burn patients.

Similarly, other studies mentioning tandir burns have stated that amputations and other surgical interventions were seen more frequently in this group. ${ }^{[3,13,14]}$ Our investigations of the different surgical treatments administered to hospitalized patients revealed that tandir burns were the type that most often required debridement, grafting and amputation. We have shown that the mortality of tandir burns was greater than that of other burns. However, while our mortality rate was $4.4 \%$, the two other studies have reported rates of $25 \%$ and $23.8 \%$. The results of Emsen et al.'s study ${ }^{[13]}$ contained no information as to mortality. The reason for our lower rate of mortality may be the fact that our study results cover the last two years, and the pre-hospital and hospital treatments of tandir burns are better than in earlier years. The low ratio of total body surface area among our cases might be another factor. This suggests that tandir injuries cause more serious and deeper burns than other types of burn injury. In patients with tandir burns, extensive burn injury and inadequate metabolic and hemodynamic resuscitation prior to reaching the burn unit may be important contributors to the high mortality rate.

Tandir burns are a local burn problem specific to the eastern and southeastern regions of Turkey. These burns, resulting from victims falling into pit-shaped ovens and coming into direct contact with fire or pit walls with a mean temperature of approximately $450^{\circ} \mathrm{C}$, and thus having a high morbidity and mortality rate, are preventable. To this end, national education and change projects (methods of baking bread with other ovens) directed at regions where bread is baked with the tandir method must be implemented. Until these projects are implemented, it must not be forgotten that the treatment of the victims before they reach the hospital must be carried out by experts and in the shortest time possible.

\section{REFERENCES}

1. Coste J, Wasserman D, Venot A. Predicting mortality in adult burned patients: methodological aspects of the construction and validation of a composite ratio scale. J Clin Epidemiol 1996;49:1125-31.

2. Bang RL, Sharma PN, Gang RK, Ghoneim IE, Ebrahim MK. Burn mortality during 1982 to 1997 in Kuwait. Eur J Epidemiol 2000;16:731-9.

3. Bekerecioğlu M, Yüksel F, Peker F, Karacaoğlu E, Durak N, Kişlaoğlu E. "Tandır": An old and well known cause of burn injury in the Middle East. Burns 1998;24:654-7.

4. Akçay MN, Oztürk G, Aydinli B, Ozoğul B. Tandir burns: a 
severe cause of burns in rural Turkey. Burns 2008;34:268-70.

5. Türkiye İstatistik Kurumu (Turkish Statistical Institute). Available at: http://tuikapp.tuik.gov.tr/adnksdagitapp/adnks.zul.

6. Baxter CR. Fluid volume and electrolyte changes in the early post burn period. Clin Plast Surg 1974;1:693-709.

7. Tarim A, Nursal TZ, Yildirim S, Noyan T, Moray G, Haberal M. Epidemiology of pediatric burn injuries in southern Turkey. J Burn Care Rehabil 2005;26:327-30.

8. Cerovac S, Roberts AH. Burns sustained by hot bath and shower water. Burns 2000;26:251-9.

9. Coban YK, Erkılic A, Analay H. Our 18-month experience at a new burn center in Gaziantep, Turkey. Ulus Travma Acil Cerrahi Derg 2010;16:353-6.

10. Anlatici R, Ozerdem OR, Dalay C, Kesiktaş E, Acartürk S, Seydaoğlu G. A retrospective analysis of 1083 Turkish pa- tients with serious burns. Burns 2002;28:231-7.

11. Edlich RF, Glasheen W, Attinger EO, Anne A, Haynes B, Hiebert JT. Epidemiology of serious burn injuries. Surg Gynecol Obstet 1982;154:505-9.

12. van Rijn OJ, Bouter LM, Meertens RM. The aetiology of burns in developed countries: review of the literature. Burns 1989;15:217-21.

13. Emsen IM, Yenidunya MO. Clay cooker (tandir) burns. Plast Reconstr Surg 2005;115:654-6.

14. Al B, Coban S, Güloğlu C. Tandir burns in and around Diyarbakır, Turkey. Ulus Travma Acil Cerrahi Derg 2010;16:59-62.

15. Bang RL, Gang RK, Sanyal SC, Mokaddas E, Ebrahim MK. Burn septicaemia: an analysis of 79 patients. Burns 1998;24:354-61. 